NBER WORKING PAPER SERIES

\title{
THE CONTROL OF STRATEGIC ALLIANCES: AN EMPIRICAL ANALYSIS OF BIOTECHNOLOGY COLLABORATIONS
}

Josh Lerner

Robert P. Merges

Working Paper 6014

\author{
NATIONAL BUREAU OF ECONOMIC RESEARCH \\ 1050 Massachusetts Avenue \\ Cambridge, MA 02138 \\ April 1997
}

Mark Edwards made this project possible by allowing very generous access to Recombinant Capital's databases. We thank seminar participants at Columbia, Harvard, the NBER Productivity and Output Measurement Group, and the State University of New York at Stony Brook for helpful comments, as well as Rebecca Henderson, Adam Jaffe, Martin Feldstein, and a number of practitioners. Support was provided by the Consortium on Competitiveness and Cooperation; the NBER Project on Industrial Technology and Productivity, with support from the Alfred P. Sloan Foundation; and Harvard Business School's Division of Research. Research assistance was provided by Tiffany Lin, John Seeg, Evan Wamsley, and especially Elizabeth Whitburn. All errors and omissions are our own. This paper is part of NBER's research program in Productivity. Any opinions expressed are those of the authors and not those of the National Bureau of Economic Research.

(C) 1997 by Josh Lerner and Robert P. Merges. All rights reserved. Short sections of text, not to exceed two paragraphs, may be quoted without explicit permission provided that full credit, including $\mathbb{C}$ notice, is given to the source. 
The Control of Strategic Alliances: An Empirical

Analysis of Biotechnology Collaborations

Josh Lerner and Robert P. Merges

NBER Working Paper No. 6014

April 1997

JEL Nos. O32, O34

Productivity

\begin{abstract}
In this paper, we examine the determinants of control rights in technology strategic alliances between biotechnology firms and pharmaceutical corporations, as well as with other biotechnology firms. We undertake three clinical studies and an empirical analysis of 200 contracts. Consistent with the framework developed by Aghion and Tirole [1994], the allocation of control rights to the smaller party increases with its financial health. The empirical evidence regarding the relationship between control rights and the stage of the project at the time the contract is signed is less consistent with theoretical frameworks.
\end{abstract}

Josh Lerner Morgan Hall, Room 395

Harvard Business School

Soldiers Field Road

Boston, MA 02163

and NBER

jlerner@hbs.edu
Robert P. Merges

School of Law (Boalt Hall), Room 225

University of California, Berkeley

Berkeley, CA 94720

rmerges@boalt.berkeley.edu 


\section{Introduction}

A crucial insight of the recent literature on the theory of the firm is the importance of control rights in determining organizational structure. The older literature on transaction costs had highlighted the difficulty of negotiating agreements as a crucial factor in determining firm structure. Recent models by Grossman, Hart, and Moore, among others [reviewed in Hart, 1995], have emphasized that the structure of firms is largely driven by events that may occur after a contract is signed, especially the possibility of opportunistic behavior or events not foreseen in the agreement. A major focus of organizational design, they argue, is insuring that power is assigned to the party which is most able to influence the outcome.

One environment where the proper allocation of control rights is particularly important is collaborative arrangements between firms to develop new technologies. Young firms with novel technologies frequently lack the financial resources to effectively introduce a new product and may find it difficult to raise equity or debt due to the informational asymmetries surrounding the project. They may also lack complementary assets (e.g., sales forces and manufacturing know-how), which often take many years to develop. As a result, strategic alliances between small, research-intensive firms and larger corporations have become commonplace.

The challenges posed by the allocation of control rights in these types of arrangements are analyzed in a theoretical work by Aghion and Tirole [1994]. The 
authors demonstrate that two factors should determine how decision rights are allocated in these agreements:

- the extent to which underinvestment by either or both of the parties jeopardizes the success of the project.

- the relative bargaining power of the two parties.

The first of these findings echoes the more general literature on incomplete contracts alluded to above. Property rights should be allocated to the smaller firm when the marginal impact of its effort is greater than that of the larger partner. This is likely to be true of projects in their earliest stages of development, where the need for difficult-tomonitor contributions by the research-intensive smaller firm is greatest.

The second prediction is motivated by the limited ability to obtain outside financing that sometimes afflicts small high-technology firms. Young research-intensive firms frequently do not generate enough cash flow from operations, and consequently must rely on outside investors. But high-technology industries over the past half-century have been characterized by wide swings in the availability of equity from public and private investors. During periods when they cannot raise capital from the capital markets, these firms are more dependent on strategic partners, and consequently have a weaker bargaining position.

This paper empirically examines how control rights are assigned in one particular environment: agreements to research and develop new products and processes between biotechnology firms and either pharmaceutical or larger biotechnology companies 
("sponsoring firms"). This is an appropriate arena in which to examine the predictions of the literature on the theory of the firm for several reasons. First, the allocation and delineation of control rights are very important in these agreements. [For survey evidence underscoring this point, see Corporate Alliances, 1993.] The prerogatives of the parties in every stage of the project-whether concerning the allocation of the research dollars, the decision to undertake patent litigation against third parties, or the marketing strategy - are painstakingly negotiated and carefully delineated in these documents.

Second, the firms entering into these contracts exhibit considerable heterogeneity. In some cases, the technologies in the agreements have received regulatory approval; in other cases, they are in the very earliest stages of research exploration. The degree of intellectual property protection similarly varies. The theoretical literature suggests that the stage of the project's development will affect the allocation of control rights. Since most biotechnology firms have expertise in early-stage research, we anticipate that many more control rights would flow to them in the early stages of the project. Established pharmaceutical firms, meanwhile, have many years of experience in managing the clinical trials that are required for Federal approval of new drugs, and consequently might be anticipated to be assigned many more of the control rights in such later-stage agreements.

Furthermore, the availability of equity from public investors for new biotechnology firms has been particularly variable. For instance, the amount raised by publicly traded biotechnology firms in follow-on offerings (in 1995 dollars) went from 
$\$ 340$ million in 1990 to $\$ 2.7$ billion in 1991 ; then fell again to $\$ 788$ million in 1992 . The financing activities of biotechnology firms between 1978 and 1995 are summarized in Figure 1 and Table 1. ${ }^{1}$ Since young biotechnology firms face enormous costs while developing new products, periods when the equity markets are "closed" create tremendous difficulties for these firms. During these periods, the bargaining power in strategic alliances is likely to shift in favor of pharmaceutical firms: practitioners frequently term such periods "buyer's markets" [e.g., Cunningham, 1994]. The theoretical literature suggests that larger firms should receive a greater share of the control rights during these periods.

Finally, technology strategic alliances are interesting in their own right. As the first panel of Table 2 suggests, the number of such agreements has been growing in a variety of industries. ${ }^{2}$ Nowhere is this clearer than in the biotechnology industry, where strategic alliances with pharmaceutical firms have become in recent years the single largest source of financing, accounting for several billion dollars of funds annually. ${ }^{3}$ The

1. We thank Mark Edwards and Hilary Shane for permission to employ some of their data.

2. These tabulations, reported in National Science Board [1996], are based on the Maasricht Economic Research Institute on Innovation and Technology's "Co-operative Agreements and Technology Indicators" database. The National Science Foundation considers the database, which is drawn from press accounts about agreements, to be an indicative, but not comprehensive, depiction of alliance activity in these three industries.

3. Because payments from pharmaceutical to biotechnology companies can be structured as equity purchases, milestone payments, and royalties, determining the cumulative amount of payments is often problematic. Using one method to calculate agreement value-summing the (nominal, not discounted) value of all pre-commercialization payments and equity purchases-suggests that alliances have in recent years exceeded the 
second panel of Table 2 illustrates the growth in the number of strategic alliances involving U.S. biotechnology firms and other private-sector entities. (Agreements with universities, other non-profits, and government bodies are excluded.) The economic importance of these transactions is illustrated by the willingness of firms to spend huge amounts litigating them and the size of the damage awards. For instance, Genentech and Eli Lilly's dispute over their collaboration to develop human growth hormone led to the filing of at least six suits between 1987 and 1993 . The dispute was ultimately settled by a payment of at least $\$ 145$ million to Genentech. Other examples of soured collaborations include that between Amgen and Ortho Pharmaceutical and between Immunex and Hoechst.

This project had two components. As an initial step, three clinical studies of strategic alliances between biotechnology and pharmaceutical firms were undertaken. These studies examined how the firms' situations influenced the allocation of control rights in these agreements. The case studies were supplemented with discussions of these issues with a variety of industry participants.

public markets as the primary source of financing. For instance, the value of these commitments in 1995 totaled $\$ 3.4$ billion; $\$ 2.3$ billion was raised from the public markets. This method is problematic because (i) not all contractually specified payments may be made (i.e., if one of the parties exercises its right to cancel the agreement), (ii) the discounted value of payments promised at future dates will be below the nominal value stated in the contract, and (iii) some of the agreements may lead to substantial royalty payments after commercialization, which are not included in these tabulations. An alternative method, also presented in Table 2, is to tabulate actual payments from pharmaceutical to biotechnology firms. This again is a somewhat misleading indication of contracting activity, as it is likely to be a function of earlier agreements. 
This empirical portion of the project employs a unique database assembled by Recombinant Capital, a San Francisco-based consulting firm specializing in documenting financial and alliance activity in the biotechnology industry. Recombinant Capital has concentrated on gathering and coding contracts from filings with the U.S. Securities and Exchange Commission [SEC] and state regulatory authorities. The analysis uses this database to examine the determinants of control rights within 200 alliances between biotechnology companies and sponsoring firms.

Consistent with the framework developed by Aghion and Tirole, the number of control rights allocated to the smaller party increases with the firm's financial health and the presence of favorable conditions in the public marketplace. Evidence regarding the relationship between control rights and the stage of the project at the time the contract is signed is less consistent with theoretical frameworks, with projects in their early stages at the time the agreement is signed actually assigning significantly less control to the smaller party. While the interpretation of this result is not unambiguous, certainly the analysis does not provide much support for this interpretation.

In view of the wealth of theoretical literature on technology licensing and alliances [dating at least back to Arrow, 1962], it is surprising that there has been relatively little prior empirical research into this issue. Much of the analysis has been focused on the question of whether firms enter into strategic alliances [e.g., Arora and Gambardella, 1990; also see the overview in Kogut, 1988]. A second avenue of research 
has been examinations of the stock price reaction to the announcements of strategic alliances [e.g., Chan, Martin, and Kensinger, 1990]. Of the limited work on the structure of collaborative arrangements, much has focused on the nature of the payments from licensees to licensors: this is true of Taylor and Silverston's [1973] survey of 26 British manufacturers, Hall's [1991] examination of 38 SEC-filed contracts, and Contractor's [1981] analysis of 102 international technology licenses. The most similar papers are Caves, Crookwell and Killing's [1983] survey of 62 licensors and licensees in a variety of industries regarding several contractual provisions, and Pisano and Mang's [1993] examination of the forms of one contractual term-the allocation of manufacturing rights-in a set of 70 agreements between biotechnology and pharmaceutical firms. ${ }^{4}$

The plan of this paper is as follows. Section 2 presents evidence from three clinical studies of strategic alliances between biotechnology and pharmaceutical firms. The third section describes the construction of the sample. Section 4 presents the empirical analysis of the allocation of control rights. The final section concludes the paper.

4. In addition to examining a broader number of terms and contracts, this work is distinguished from these examinations by its joint emphasis on how deal structures change with the risk of underinvestment and with the relative bargaining power of the parties. Another body of work related to this paper examines the determinants of terms in procurement contracts [e.g., Joskow, 1987; Crocker and Reynolds, 1993]. The papers in this literature most similar to this one are Hubbard and Weiner's [1991] examination of natural gas supply contracts and Gompers and Lerner's [1996] study of venture partnership agreements, which test whether contractual restrictions are determined by potential for opportunistic behavior after the contract is signed or the bargaining power of the parties at the time of the negotiation. 


\section{Evidence from Clinical Studies}

As part of the effort to understand the structure of strategic alliances between biotechnology and pharmaceutical firms, one of the authors undertook a series of three clinical studies. The studies examine three young companies developing advanced pharmaceutical technologies that are grappling with the challenges posed by strategic alliances. The biotechnologies pursued by the three firms are quite different: antigenbased allergy drugs (ImmuLogic Pharmaceutical Corporation), advanced drug delivery mechanisms (ALZA Corporation), and monoclonal antibody-based treatments of inflammation (Repligen Corporation). The strategic partners ranged in their location and sophistication; the technologies in their stages of development. ${ }^{5}$

These examinations-captured in ten case studies and three teaching notes [Lerner, 1992; Lerner and Tufano, 1993; Kane and Lerner, 1994]—were based on public securities filings, internal corporate documents, and repeated interviews with senior managers of these firms. Supplemental discussions were held with investors, outside directors, strategic partners, and other observers. A detailed discussion of these alliances is beyond the scope of this paper: the interested reader is referred to the case studies and associated teaching notes. In this section, however, we briefly discuss how control rights were allocated in these alliances, and the parallels to the theoretical literature summarized above.

5. The preparation of these cases were complemented by a series of academicpractitioner roundtable discussions on the role of strategic alliances in the biotechnology industry organized by one of the authors. 
The importance of both ex post opportunism and bargaining power are illustrated by how the control rights were allocated in these cases. One alliance that may be considered in many respects successful was Repligen's agreement with Eli Lilly regarding a very early-stage effort to develop a monoclonal antibody-based treatment of inflammation after heart attacks. ${ }^{6} \quad$ In the negotiations, there were three areas where control rights were in dispute. The first was the management of clinical trials: which drugs would be pursued and when. A second was the control over the marketing strategy, an arena in which Lilly had extensive experience and Repligen only a slight acquaintance. Finally, both parties wished to undertake the process development and ultimate manufacturing of the drug. Repligen, in fact, had recently acquired a cell culture facility and the key personnel that went with it.

The final agreement appeared to assign the control rights to the parties with the greatest discretion to behave opportunistically. Repligen was allowed a great deal of flexibility in developing the lead product candidate (where it had the most experience), but tangential product development activities would only be supported if precise milestones were reached. Lilly was assigned control over all aspects of marketing; while Repligen was assigned all manufacturing control rights, unless it encountered severe difficulties with regulators.

6. The net-of-market return for Repligen in the three day window around the announcement of the transaction in May 1992 was $+9 \%$; that of Lilly, $+2 \%$. The earlystage project succeeded in getting its lead product candidate into Phase I trials in just 
Other agreements illustrate the importance of the relative bargaining power of the two parties. An example was the January 1978 agreement between ALZA and CibaGeigy. At the time of the agreement, ALZA faced a major financial crisis. The firm had little more than $\$ 1$ million in the bank; was spending \$2 million more per month than it was receiving in revenues; had nearly exhausted its bank credit line; was in violation of several loan covenants; and was precluded from a sale of equity to the public by unfavorable market conditions and the perception that ALZA had been excessively optimistic in its earlier communications with investors and analysts. The agreement assigned almost total control to the Swiss pharmaceutical giant. Ciba-Geigy was given a super-majority on the joint board that reviewed and approved potential research projects, the right to license and manufacture any of ALZA's current or future products, the ability to block any other collaborations that ALZA proposed to enter into, and eight of the eleven seats on ALZA's board of directors.

A contrasting illustration was presented by ImmuLogic. In March 1991, the firm was considering either entering into a strategic alliance or raising equity in an initial public offering. One concern that led the firm to decide to go public was that a potential strategic partner might exploit its relatively weak financial condition: i.e., a pharmaceutical company might obtain numerous concessions on key governance and financial issues by protracting the negotiations until ImmuLogic was close to running out

thirteen months. After extending the project in June 1995, however, Lilly canceled its involvement three months later, citing shifting internal priorities. 
of capital. It consequently deferred negotiating a strategic alliance to develop and market its allergy drugs until after going public in May 1991. The firm announced an agreement with Marion Merrell Dow in December 1991, which allowed ImmuLogic to retain numerous control rights, such as an equal role in planning marketing strategy in the U.S.: In Vivo magazine hailed the transaction as "push[ing] the limit of the biotech deal ... a partnership in fact as well as name." Just as ALZA's relinquishment of almost total control to Ciba-Geigy was in large part a consequence of its weak financial position, ImmuLogic's ability to obtain these control rights reflected its financial strength.

At the same time, the cases emphasize two issues that are not highlighted in the theoretical literature (or in the empirical analysis in this paper). One is the interaction between the allocation of control rights and the financial terms of the transactions. For instance, in the negotiations that led to Repligen's retention of control over manufacturing, the firm agreed to an alteration in its compensation. Repligen accepted a lower royalty than originally envisioned $-5 \%$ of the sales price — but agreed to supply the drug to Lilly at a price (about $15 \%$ of the sales price) above what it believed its true manufacturing cost would be. Repligen agreed reduce the price that it charged Lilly if it was able to manufacture the drug for less, but only if its cost was below $8 \%$ of the sales price.

A second interesting and quite unexplored aspect is the apparent signal that the allocation of control rights provided to potential investors and other outsiders. Both ImmuLogic and Repligen highlighted their retention of key control rights in the press 
releases announcing the transactions. Their ability to obtain these rights attracted favorable comments in the trade press and analyst reports alike. These patterns suggest a richer set of interactions than most theoretical treatments of these issues imply.

\section{Construction of the Sample}

The empirical analysis was based on a database of contracts compiled by Recombinant Capital, a San Francisco-based consulting firm specializing since 1988 in tracking the biotechnology industry. Publicly traded biotechnology firms, like other concerns, are required by the SEC to file "material" documents. Biotechnology companies tend to interpret this requirement conservatively, and often file strategic alliances. This may partially reflect the fact that firms typically do not have a great deal of sales. Consequently, contractual payments represent a large share of their total revenues. This practice also appears to reflect industry practice: publicly traded multimedia developers, for instance, also often have very little revenue outside of contractual payments, but rarely file their agreements with media companies. These contracts are typically filed as amendments to $10-\mathrm{K}, 10-\mathrm{Q}, \mathrm{S}-1$, or $8-\mathrm{K}$ statements. In addition, a number of state governments require privately held companies with employee stock option plans to file material documents and make these documents available to the public. These are also collected and coded by Recombinant Capital.

As of July 1996, Recombinant Capital had identified from SEC filings, news accounts, and press releases approximately 3500 alliances between private firms (as opposed to those involving universities, hospitals, non-profit research institutions, or the 
Federal Government). Of these, approximately 500 had been analyzed by Recombinant Capital through this date. Recombinant Capital seeks to ascertain any information that has been deleted from the filed contracts by examining subsequent filings by the firm, which often enable the determination of redacted royalty rates or lump-sum payments. ${ }^{7}$ This database is typically licensed by major pharmaceutical, accounting, and law firms for a considerable annual fee and has not been hitherto made available to academics. ${ }^{8}$

We selected a random sample of 200 of the analyzed contracts to encode. We sought to create a population that avoided undesirable heterogeneity. In particular, we eliminated contracts where:

- one of the parties was a university, medical center, other non-profit organization, or government agency;

- one of the parties had a controlling interest in the other, either through a majority equity stake or through a purchase option (e.g., a contract between a firm and one of its R\&D limited partnerships);

- the two parties had a previous contractual relationship covering the same set of technologies, and consequently were primarily renegotiating the terms of an earlier agreement;

- there was neither a research nor a product development component, but the contract simply involved the marketing of an existing product;

- more than two firms were involved, making the analysis of the division of control rights less tractable.

7. Firms can request confidential treatment for the key information in these contracts. Their failure to disclose this information, however, may become an issue if the firm is sued for security law violations. (Shareholder class-action litigation has been a frequent event in high-technology industries.)

8. A less detailed version of the database, however, is available for public use [Recombinant Capital, 1996]. 
As part of its analysis, Recombinant Capital divides the contractual terms into 58 categories and summarizes them. These classifications and descriptions are prepared according to a systematic approach developed by Mark Edwards, Recombinant Capital's managing director. We tabulated each of the text fields in a database that summarized the key control features.

For each of the 200 agreements, we gathered a variety of supplemental information:

- the progress of the project under development, as measured by the stage of the project in the regulatory approval process at the time of the agreement. This information was determined by Recombinant Capital from federal and corporate documents.

- the progress of the project under development, as measured by the number of patent awards to the smaller biotechnology firm in the same area as the agreement and the total number of patents awarded to the biotechnology firm. Only U.S. patents awarded at the time of the agreement were tabulated. Patents in the same area as the strategic alliance were determined through searches of the LEXIS's PATENTS/ALL database, using keywords from the agreements. We included awards to these firms' subsidiaries, joint ventures, and R\&D limited partnerships. We identified name changes, joint ventures, subsidiaries, and research and development limited partnerships from a variety of reference sources [described in Lerner, 1994].

- the relative bargaining power of the biotechnology firm, as measured by public market conditions for biotechnology firms at the time of the agreement. We compiled from a variety of sources the total volume of public equity issues by biotechnology firms in the quarter and year immediately preceding the transaction, as well as the level of the biotechnology equity index at the end of the quarter immediately prior to the offering. [See Lerner, 1994, for a detailed description.]

- the relative bargaining power of the biotechnology firm, as measured by its financial status. We compiled key financial data (e.g., total assets, shareholders' 
equity, cash and equivalents, etc.) from Compustat for the end of the fiscal year immediately prior to the agreement. For firms where this information was not available from Compustat, we gathered the information from $10-\mathrm{K}$ filings, IPO prospectuses, and other SEC filings.

Table 3 summarizes the key characteristics of the agreements, as well as those of the firms entering into these agreements.

Several patterns can be observed from these summary statistics. First, the observations are concentrated towards the end of the sample. This reflects not only the increasing level of alliance activity in recent years (documented in Table 2), but also Recombinant Capital's propensity to code more recent contracts. (These are presumably of greater interest to its clients.) Second, the table displays the very early stage at which most of these alliances are arranged: in nearly two-thirds of the cases, pre-clinical development (animal studies) had not yet begun. Third, the precarious financial health of these R\&D firms is apparent. The typical firm in the fiscal year before the agreement had taken in almost $\$ 10$ million in revenue (primarily grants, interest earnings, and payments associated with other collaborative arrangements), but had expenditures of over $\$ 21$ million (mostly on R\&D). The loss in the prior year represented one-third of the average firm's shareholder equity and nearly one-half of its cash and equivalents. By way of contrast, the average firm financing R\&D in these alliances had $\$ 6.4$ billion in sales, $\$ 562$ million in net income, and $\$ 6.9$ billion in total assets in the year before the agreement.

\section{Empirical Analysis}

In this section, we analyze the relationship between the control rights in these agreements and the characteristics outlined above. First, we recount how the twenty-four 
control rights that we study were identified. We then present both univariate correlation and regression analyses of the determinants of these rights.

\section{A. Identifying the Control Rights}

These contracts are complex documents. Many variants of each control right are found in the contracts. To illustrate this point, consider the terms relating to the control of patent litigation. In some cases, the right to defend patent rights is explicitly assigned to one of the two parties. In other instances, a joint committee makes the key determinations regarding whether to sue and about the litigation strategy, or the control of litigation is divided by geography or product. Elsewhere, if one party does not initiate litigation with a certain number of days of becoming aware of an infringing patent, the control rights transfer to the other party. In some cases this issue is not addressed at all, or acknowledged as an issue that will be addressed by the parties if and when the situation arises. It is interesting to note that the control rights are often linked to the financing of the litigation. For instance, in some instances if the firm financing the R\&D exercises its first option to pursue litigation, it bears half or more of the expenses of the lawsuit. If the larger firm does not exercise the option, and the firm being funded chooses to pursue the litigation, then often the smaller firm bears the entire expense.

Fully capturing the complexity of these rights in an empirical analysis is difficult. We focus in this paper on examining the overall allocation of the control rights in these agreements. We first examine five control rights that case studies, publications, and conversations with practitioners suggest are critical issues in the negotiation of strategic 
alliances. We then examine twenty-four control rights in these contracts. These include all rights found in at least five percent of the agreements in our sample and no more than 95 percent of agreements.

The first of the five key sets of control rights relates to the management of the clinical trials. Not only are applications for regulatory approval of bio-engineered therapeutic and agricultural processes exceedingly protracted and costly, but they involve many decision points. A therapeutic may have several different potential uses, and choosing which indication to pursue initially is often contentious. For instance, the pharmaceutical company may not wish to address a disease where it has an existing product, lest it cannibalize existing sales, while the biotechnology firm may believe that this application shows the greater promise.

A second area for frequent negotiations is the control of manufacturing. This has two aspects. The first relates to the development of the initial manufacturing process. In many cases, the processes discovered at the test-tube level may need to be fundamentally altered as manufacturing is scaled up. As a result, process development can be an important source of insights into the underlying science [Pisano and Mang, 1993]. The retention of manufacturing rights also is a significant control right, particularly for human therapeutic products. When the U.S. Food and Drug Administration (FDA) approves a new drug, the approval extends only to the particular facility where it is being manufactured. If a pharmaceutical company seeks to move production from the facility of a strategic partner to one of its own, it must undergo 
another extensive and time-consuming FDA review. Thus, the assignment of manufacturing rights is frequently an item of contention.

A third area of intensive negotiation is marketing rights. Almost all pharmaceutical firms have large sales forces, which engage in the time-consuming process of developing personal relationships with doctors and hospital administrators. At least until very recently, most biotechnology firms have sought to develop such capabilities. Not only did these firms believe that a sales force would allow them to increase their profit margins, but that the information gathered through this sales force would be of strategic importance. Consequently, a frequent issue in negotiations is whether the larger firm will have the exclusive right to market the eventual product, or whether the smaller biotechnology firm will share in the marketing endeavor. Biotechnology companies have been involved in marketing in two ways: either they receive exclusive rights to market the product in one or more markets (i.e., a particular country or disease indication) or else receive "co-marketing" rights. These allow the smaller firm to be involved as a partner in the marketing of the product in one or more markets.

While these issues were the most frequently mentioned in discussions and case interviews, many other control rights also figured in these agreements. We consequently identify the broad control rights that appeared in between 10 and 190 out of the 200 contracts. In this way, we enhance the tractability of the analyses by eliminating 
several classes that are either standardized "boilerplate" or else exceedingly rare. In the remainder of this section, we briefly discuss these additional classes.

The first set of additional control rights address alterations to the scope of the alliance. Several contracts provide the funding firm with the right to expand the breadth of the alliance, either by adding to the technologies under development or by extending the duration of the project. At the other extreme, nearly all alliances include some provisions for the cancellation of the alliance in particular circumstances (e.g., the bankruptcy or acquisition of one of the parties). In some cases, however, the larger partner has the right to cancel the agreement without cause, or to terminate particular projects. A related cluster of terms address the control of the licensed technologies. In some cases, the firm funding the R\&D has broad powers to sub-license the technology to other firms and to continue to sell projects developed, even after the alliance ends. In other cases, these rights are much more limited. In a few alliances, the smaller firm can even reclaim the licensed technologies from its partner if the pace of development is not aggressive enough.

The second cluster of control rights relate to intellectual property. Patents and associated scientific knowledge are the most important assets of many biotechnology firms, so it is not surprising that they would be the focus of contractual discussions. Because lawsuits are such a important a way to determine the extent of intellectual property protection in the biotechnology industry, much of the contractual language 
examines who will control of patent litigation process. Related control rights identify who will own the patents generated by the collaboration.

Other contractual provisions relate to unpatented intellectual property, often referred to as "know-how." Some contracts include stipulations that the larger firm is entitled to transfers of smaller firm's know-how; in a few cases, ownership of the unpatented core technology is assigned to the firm funding the R\&D. The control of the smaller firm's scientific publications are also a frequent item of contractual discussions. Many biotechnology firms recruit academic researchers, who are eager to maintain an active publication record. Important publications by employees of a small biotechnology firm may also serve as a favorable signal to the stock market [e.g., Kane and Lerner, 1994]. But premature publications may jeopardize the ability of the parties to obtain patent protection. More generally, many pharmaceutical companies are reluctant to allow their employees to publish scientific work [Henderson and Cockburn, 1996]. Consequently, the larger corporation sometimes obtains the right to delay publications of the smaller firm or even to suppress them entirely.

The final area for the frequent provision of control rights in these agreements is the governance of the alliance. These control rights take two forms. First, these strategic alliances typically have one or more boards that oversee the collaboration. While control of the governing board is typically divided evenly between the two firms, occasionally the funding firm is assigned the chairmanship or the tie-breaking vote. 
Second, the firms funding the R\&D have adopted many of the control rights employed by venture capital organizations while financing small private firms. [For an analysis of the control rights in venture financing of the biotechnology firms, see Lerner, 1995; for a more general overview, see Fenn, Liang, and Prowse, 1995.] These include a seat on the firm's board, as well as an equity stake in the firm (with the associated voting rights). In many cases, instead of receiving common stock, the funding firm receives preferred shares with additional control rights. Among these are the right to participate in future financings of the firm on a pro rata basis or anti-dilution provisions (which make it difficult for the R\&D performing firm to sell shares at a lower price). These provisions give the larger corporation substantial control over the R\&D performing firm's ability to raise outside financing, and consequently over the firm's future direction. Registration rights can be even more onerous, as they provide a mechanism through which the larger firms can demand that the smaller firm arrange for the sale of its shares in the public market (which may be very costly or at times impossible to arrange). Finally, the smaller firm may seek to retain its autonomy by obtaining a commitment from the larger firm not to purchase additional shares in the public market. If the larger firm believes that it may ultimately want to acquire the smaller firm (or wants to preserve the threat of such an acquisition), it may be reluctant to agree to such a "stand-still" provision.

Table 4 summarizes the frequency with which these 24 control rights appear in the sample. In each case, the variables are binary ones, with a value of 1.0 indicating that the particular right is allocated in a way that favors the larger partner. The contracts 
are divided into four chronological periods. No clear time trend in the overall allocation of control rights is apparent in the summary statistics. In the sample contracts, the number of control rights (out of the possible 24) assigned to larger firm varies from four to fifteen.

\section{B. Empirical Analyses}

In this section, we analyze the use of these provisions. In both the correlation and regression analyses, we find evidence consistent with the hypothesis that the financial condition of small biotechnology firms affects their ability to retain control rights in strategic alliances. Evidence regarding the potential for opportunistic behavior is more mixed: while several of the coefficients of these variables have significant explanatory power, their signs are not always consistent with theoretical suggestions.

The initial analysis is presented in Table 5. We examine the correlation between the number of control rights and the various characteristics of the firm being financed and the public equity market at the time of the agreement. As discussed above, we examine both five key control rights and the twenty-four rights that appear in between $5 \%$ and $95 \%$ of the contracts.

Our empirical approach has some important limitations. In particular, we are implicitly assuming that each control right is as important as the others. This is unlikely to be the case. We are also ignoring the considerable heterogeneity within the particular control rights. Consider, for instance, the variable denoting the control of patent 
litigation. We indicate that the larger firm has control of the patent litigation process whether or not the smaller firm has the option of taking control of the litigation if the larger firm does not pursue it, and whatever the rules are for sharing the cost of the litigation.

The correlation analysis presents mixed results. Using both measures, there is a strong negative relationship between the number of control rights allocated to the larger firm and the financial strength of the smaller concern. Biotechnology firms with more revenues in the year before the agreement is signed, as well as those spending more on $\mathrm{R} \& \mathrm{D}$ and having more financial resources, are less likely to negotiate away important control rights. ${ }^{9}$

When we examine only the five key control rights, other significant patterns emerge. Since these control rights were all identified as critical issues in negotiations, it is not surprising that the counts of these provisions generate more statistically significant results. It is likely that these provisions are a less noisy measure of the allocation of control. When more equity is raised by biotechnology firms in the public markets during the quarter preceding the signing of the alliance, fewer control rights are assigned to the

9. It may seem surprising that there is not a strong relationship between net income and the allocation of control rights. This reflects the peculiar economics of the biotechnology industry. While firms attracting more external research funding and receiving revenues from product market sales will report higher net income, early-stage companies with significant financial resources may spend more aggressively on R\&D and consequently report lower net income (greater losses) than their less well-endowed peers. Thus, net income is a very imperfect indicator of the financial health of young biotechnology firms. 
large firm. This is consistent with the patterns found using the measures of the smaller firm's financial condition.

The interpretation of the results using the measures of the stage of the project are more problematic. When the technology is in its early stages or the smaller firm has fewer patents, there are significantly more control rights allocated to the larger firm. This seems to contradict theoretical suggestions, since we would anticipate that the possibility for opportunism by the smaller firm and for unforeseen contingencies in product development would be greatest in those settings with substantial informational asymmetries. Since these are partial correlations, however, they may reflect the impact of other factors: e.g., firms with few patents tend to be younger ones with few financial resources and weak bargaining positions.

To address these concerns, we examine the allocation of control rights in a regression framework. As a dependent variable, we employ the number of control rights allocated to the firm. Once again, we look at the both five crucial control rights and the broader set of 24 rights. We employ two specifications: a straightforward ordinary least squares regression, as well as an ordered logit approach. The latter specification avoids some of the problems associated with the differing importance of the various control rights: such a regression treats a contract assigning twelve control rights to the funding party as more favorable to the larger firm than one with six such control rights, but not necessary twice as favorable. 
We employ a variety of independent variables in the regressions. These include a dummy variable denoting early-stage projects at the time of signing of the agreement (that is, those between the earliest discovery stage and pre-clinical research), the number of patent awards to the smaller firm in fields related to the agreement, the amount of equity raised by biotechnology firms from the public markets in the previous quarter, the index of biotechnology equity valuations, and two measures of the financial resources of the smaller firm (shareholders' equity and total assets). All financial variables are expressed in billions of 1995 dollars.

The results are reported in Tables 6 and 7. In each case, the measures of the financial condition of the firm are significantly negative, at least at the five percent confidence level: when the smaller firm is in a healthier financial position, it retains more of the control rights in the strategic alliance. The coefficients suggest that these considerations have a significant economic impact. For instance, in the first regression in Table 7, a one standard deviation increase in shareholders' equity at the mean of the independent variables leads to a $10.4 \%$ drop in the predicted number of control rights assigned to the larger firm (from 8.6 to 7.7). In several of the regressions, the measures of external market conditions also have a significantly negative relationship with the number of control rights that the larger firm receives in the contract.

The evidence regarding the stage of the agreement, however, is somewhat counter to theory: agreements consummated in the early stages of a project tend to allocate more, 
not fewer, control rights to the firm financing the R\&D. When the number of patents is used instead as an independent variable, however, the effect is in the predicted direction. Small firms entering into agreements with strong patent positions (where, we may anticipate, much of the research has been undertaken and information asymmetries has been sharply reduced by the information in the patent awards) are assigned fewer control rights.

We also explore a variety of other specifications. These include the substitution of several alternatives for the independent variables: e.g., the amount of public equity raised by biotechnology firms in the previous four quarters for the measures of the previous quarter's fundraising or the biotechnology index, and the measures of the smaller firm's sales, R\&D, and cash and equivalents instead of assets or shareholders' equity. We also explore adding additional control variables, such as a continuous variable for the date of the agreement and dummy variables for particular periods. To examine whether the results may be driven by a few outliers, we express the continuous independent variables in logarithms. We also explore the robustness of the results to the addition and subtraction of particular control rights (e.g., using only those control rights that appear in between $10 \%$ and $90 \%$ of the agreements). All these changes have relatively little influence on the strong positive relationship between the smaller firm's financial condition and the number of control rights that it retains, or the much more ambiguous relationship between the stage at which the agreement is entered into and the allocation of control rights. 
One interpretation of these results which may be consistent with the GrossmanHart-Moore framework is the suggestion that the danger of ex post opportunism increases rather than decreases as the project matures. A biotechnology firm with a patent-or a series of related patents - may actually find it easier to behave opportunistically. Patent awards imply that any activity not expressly permitted of the licensee is prohibited. There may be a real danger that after the sponsoring firm invests a considerable amount of money, the biotechnology firm might find a technicality, terminate the agreement on the grounds that the larger firm has breached the agreement, and sue its former partner for patent infringement. Thus, the need to allocate many contractual control rights to the biotechnology concern might instead increase as the project matures. ${ }^{10}$

\section{Conclusion}

In this paper, we examine the determinants of control rights within alliances between biotechnology companies and sponsoring firms. We undertake three in-depth clinical studies as well as an empirical analysis of 200 contracts. Consistent with the

\footnotetext{
${ }^{10} \mathrm{We}$ discussed these results with a number of practitioners. These included business development officials responsible for negotiating licensing arrangements, senior officials of smaller biotechnology firms, and others who have worked closely with the industry (e.g., venture capitalists and consultants. Our findings regarding the importance of financial constraints on the allocation of control rights met with nearly total agreement. The results regarding the stage of project were more controversial. Some believed that control rights are indeed generally allocated to the party with the greater capacity for opportunistic behavior, and that our level of analysis was simply too crude to pick up many of the patterns. Others believed that the allocation of control rights are dominated by the presence or absence of financial constraints, and that any other effects are secondorder.
} 
framework developed by Aghion and Tirole [1994], the allocation of control rights to the smaller party increases with its financial health. Evidence regarding the relationship between control rights and the stage of the project at the time the contract is signed is less consistent with theoretical frameworks.

These findings, which underscore the importance of external financing, are somewhat provocative. Aghion and Tirole create a model where the allocation of control rights are affected by the potential for ex post opportunism and the availability of financing for the smaller firm. The considerable majority of the literature on the allocation of control rights in alliances, however, has focused only on the first of these factors. But this paper suggests that the most profound effect on the allocation of control rights in this industry is caused by shifts in the availability of capital to small biotechnology firms.

The paper also suggest a series of further research questions. Central among these is why the availability of equity financing for biotechnology firms has shifted so dramatically over the past two decades. Similar discontinuities have characterized the financing environment for young firms in many other high-technology industries since the $1950 \mathrm{~s}-$ including manufacturers of scientific instruments, computer hardware and peripherals, and software-as well as young firms more generally [Ibbotson, Sindelar, and Ritter, 1988]. 
One possibility is that these shifts are optimal responses to the changing information about these complex technologies and markets. Certainly, disappointing drug trials in 1992 and 1993 led to pessimism about the prospects for young biotechnology firms and contributed to these firms' subsequent difficulties in raising financing. Many practitioner accounts, however, express the opinion that the shifts in the availability of financing should be characterized as over-reactions: at times, it is either too difficult or too easy for young firms to obtain capital. Some apparent support for these claims are seen, for instance, in the dramatic shifts occurred in the availability of venture capital financing for small technology-intensive firms. Partially due to the relaxation of regulatory constraints on institutional investors, the (inflation-adjusted) in-flow of funds into venture capital increased 61-fold between 1977 and 1983. This was followed by a $73 \%$ drop between 1987 and 1991, and a 193\% increase in the two subsequent years. [For further examinations of this phenomenon, see Gompers, 1995, and Gompers and Lerner, 1996; a similar pattern is documented in Kaplan and Stein, 1993]. Exploring the source of equity financing cycles, and their implications for the behavior of firms in hightechnology industries, appears to be a fertile avenue for further research. 


\section{References}

Aghion, Phillipe, and Jean Tirole, 1994, "On the Management of Innovation," Quarterly Journal of Economics. 109, 1185-1207.

Arora, Ashish, and Alfanso Gambardella, 1990, "Complementarity and External Linkages: The Strategies of Large Firms in Biotechnology," Journal of Industrial Economics. 38, 361-379.

Arrow, Kenneth J., 1962, "Economic Welfare and the Allocation of Resources for Invention," in Richard R. Nelson, editor, The Rate and Direction of Inventive Activity: Economic and Social Factors. Princeton: Princeton University Press.

Caves, Richard, Harold Crookwell, and J. Peter Killing, 1983, "The Imperfect Market for Technology Licenses," Oxford Bulletin of Economics and Statistics. 45, 223-48.

Contractor, Farok J., 1981, International Technology Licensing. Lexington, Mass.: Lexington Books.

Corporate Alliances: Strategies in Biotechnology, 1993, San Francisco: KMPG Peat Marwick, Biotechnology Industry Organization, and Pittiglio, Rabin, Todd \& McGrath.

Crocker, Keith J., and Kenneth J. Reynolds, 1993, "The Efficiency of Incomplete Contracts: An Empirical Analysis of Air Force Engine Procurement," Rand Journal of Economics. 24, 126-46.

Cunningham, Brian, 1994, "Issues and Trends in Biotech Corporate Partnering," Palo Alto: Cooley, Godward, Castro, Huddleston \& Tatum.

Fenn, George W., Nellie Liang, and Stephen Prowse, 1995, The Economics of the Private Equity Market. Washington: Board of Governors of the Federal Reserve System.

Gompers, Paul A., 1995, "Optimal Investment, Monitoring, and the Staging of Venture Capital," Journal of Finance. 50, 1461-1489.

Gompers, Paul A., and Josh Lerner, 1996, "The Use of Covenants: An Empirical Analysis of Venture Partnership Agreements," Journal of Law and Economics. 36, 463-498.

Hall, Christopher D., 1991, "Renting Ideas," Journal of Business. 64, 21-48.

Hart, Oliver D., 1995, Firms, Contracts, and Financial Structure. New York: Oxford University Press.

Henderson, Rebecca, and Iain Cockburn, 1996, "Scale, Scope, and Spillovers: The Determinants of Research Productivity in Drug Discovery," Rand Journal of Economics. 27, 32-59.

Hubbard, R. Glenn, and Weiner, Robert J., 1991, "Efficient Contracting and Market Power: Evidence from the U.S. Natural Gas Industry," Journal of Law and Economics. 34, 25-67.

Ibbotson, Roger G., Jody L. Sindelar, and Jay R. Ritter, 1988, "Initial Public Offerings," Journal of Applied Corporate Finance. I (Summer), 37-45. 
Joskow, Paul L., 1987, "Contract Duration and Relationship-Specific Investments: Empirical Evidence from Coal Markets," American Economic Review. 77, 168-185.

Kane, David, and Josh Lerner, 1994, "Repligen Corporation: January 1992," Harvard Business School Case No. 9-294-082 (and Teaching Note 5-295-137).

Kaplan, Steven N., and Jeremy Stein, 1993, "The Evolution of Buyout Pricing and Financial Structure in the 1980s," Quarterly Journal of Economics. 108, 313-358.

Kogut, Bruce, 1988, "Joint Ventures: Theoretical and Empirical Perspectives," Strategic Management Journal. 9, 319-332.

Lerner, Josh, 1992, "ImmuLogic Pharmaceutical Corporation," Harvard Business School Cases No. 9-293-066 through 9-293-071 (and Teaching Note 5-293-118).

Lerner, Josh, 1994, "Venture Capitalists and the Decision to Go Public," Journal of Financial Economics. 35, 293-316.

Lerner, Josh, 1995, "Venture Capitalists and the Oversight of Private Firms," Journal of Finance. $50,301-318$.

Lerner, Josh, and Peter Tufano, 1993, "ALZA and Bio-Electro Systems," Harvard Business School Cases No. 9-293-124 through 9-293-127 (and Teaching Note 5-296-060).

National Science Board, 1996, Science and Technology Indicators--1996. Washington: Government Printing Office.

Pisano, Gary P., and Paul Y. Mang, 1993, "Collaborative Product Development and the Market for Know-How: Strategies and Structures in the Biotechnology Industry," Research on Technological Innovation, Management and Policy. 5, 109-136.

Recombinant Capital, 1996, http://www.recap.com.

Shane, Hillary, 1994, "Asymmetric Information and Alliance Financing in the Biotechnology Industry," Unpublished working paper, Wharton School, University of Pennsylvania.

Taylor, Christopher T., and Zangwill A. Silberston, 1973, The Economic Impact of the Patent System: A Study of the British Experience. Cambridge: Cambridge University Press. 


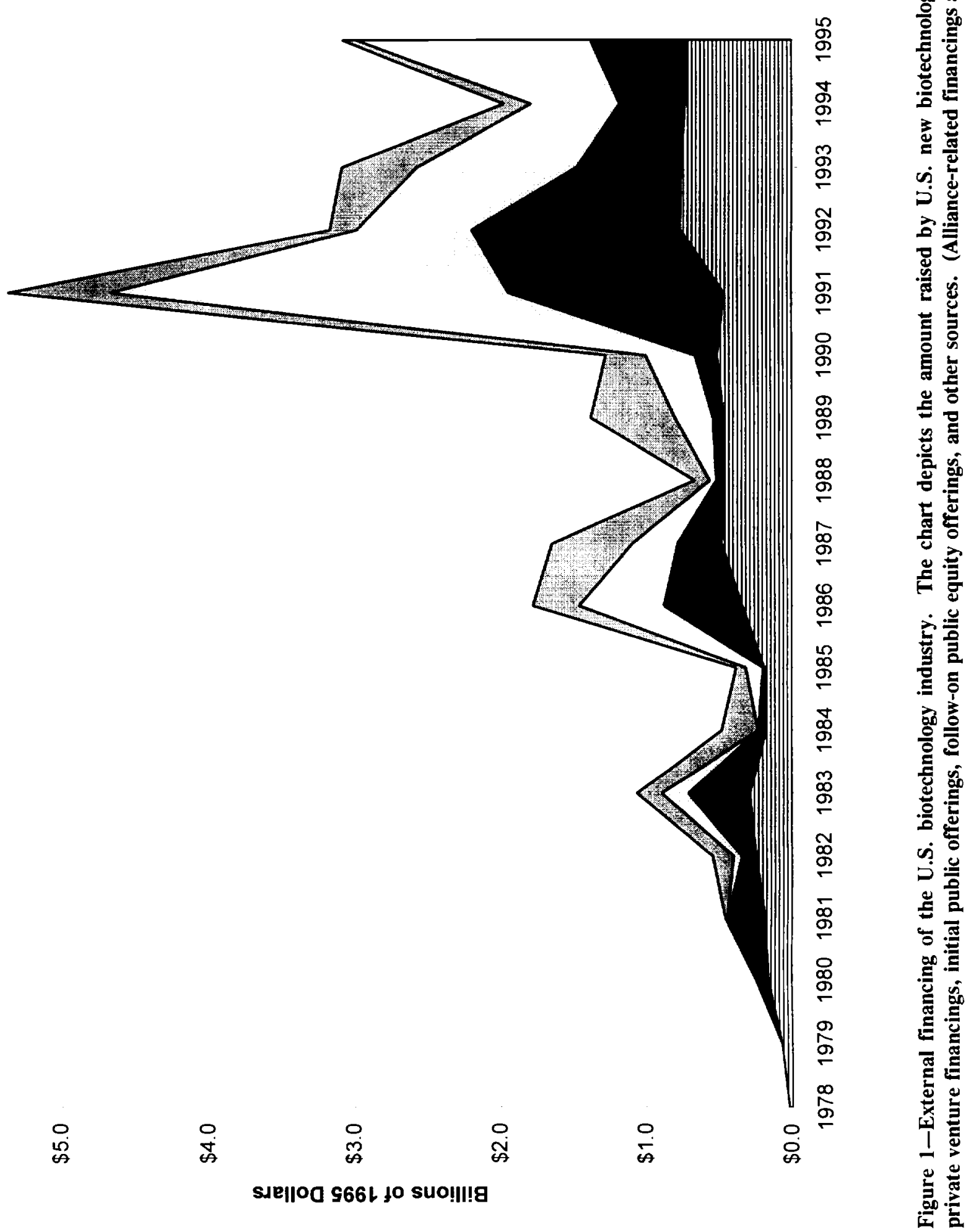







Table 2-The extent of inter-firm strategic alliances in three industries, and by biotechnology firms. The first panel presents the number of publicized alliances by U.S. firms in three industries-information technology, biotechnology, and advanced materials-between 1980 and 1994 . The second panel examines only SEC- or state-filed inter-firm alliances involving U.S. biotechnology companies between 1981 and 1995. Presented are the number of new filed alliances each year, the sum of all promised pre-commercialization payments in the filed agreements that year (the sum of the nominal payments is expressed in billions of 1995 dollars), and the actual payments to a sample of 49 of the largest biotechnology firms in each year (in billions of 1995 dollars).

\begin{tabular}{|c|c|c|c|}
\hline \multicolumn{4}{|c|}{$\begin{array}{c}\text { Panel A: Inter-Firm Alliances by U.S. Firms in Three Industries, 1980-1994 } \\
\text { Number of New Alliances Publicized, by Nationality of Firms }\end{array}$} \\
\hline Year & U.S.-U.S. & U.S.-Europe & U.S.-Japan \\
\hline 1980 & 42 & 40 & 15 \\
\hline 1981 & 48 & 30 & 26 \\
\hline 1982 & 57 & 54 & 39 \\
\hline 1983 & 51 & 37 & 51 \\
\hline 1984 & 88 & 60 & 55 \\
\hline 1985 & 86 & 82 & 52 \\
\hline 1986 & 118 & 78 & 47 \\
\hline 1987 & 133 & 95 & 53 \\
\hline 1988 & 141 & 98 & 39 \\
\hline 1989 & 122 & 86 & 44 \\
\hline 1990 & 121 & 66 & 34 \\
\hline 1991 & 106 & 53 & 51 \\
\hline 1992 & 155 & 89 & 43 \\
\hline 1993 & 192 & 104 & 45 \\
\hline 1994 & 235 & 145 & 40 \\
\hline \multicolumn{4}{|c|}{ Panel B: Inter-Firm Alliances by U.S. Biotechnology Firms, 1981-1995 } \\
\hline & Number of New & Pre-Commercial Payments & Actual Payments During \\
\hline Year & Filed Alliances & Promised in New Alliances & Year to 49 Leading Firms \\
\hline 1981 & 30 & & 0.01 \\
\hline 1982 & 35 & & 0.11 \\
\hline 1983 & 31 & & 0.15 \\
\hline 1984 & 42 & & 0.21 \\
\hline 1985 & 57 & & 0.15 \\
\hline 1986 & 63 & & 0.18 \\
\hline 1987 & 62 & & 0.42 \\
\hline 1988 & 64 & & 0.30 \\
\hline 1989 & 71 & & 0.20 \\
\hline 1990 & 81 & & 0.85 \\
\hline 1991 & 115 & 0.74 & 0.65 \\
\hline 1992 & 75 & 0.93 & 0.39 \\
\hline 1993 & 113 & 1.37 & 0.81 \\
\hline 1994 & 66 & 1.77 & \\
\hline 1995 & 171 & 3.42 & \\
\hline
\end{tabular}

Source: The first panel is from National Science Board [1996]. The number of new alliances and precommercialization payments series are from Recombinant Capital [1996] and its unpublished databases. The actual payments series is from Shane [1994]. It has not been extended beyond 1993 or to include additional firms. 
Table 3-Characteristics of the sample. The sample consists of 200 technology strategic alliances initiated between biotechnology and pharmaceutical companies or between biotechnology firms in the 1980-1995 period. The table summarizes the financial market conditions around the time of the agreement and the characteristics of the firm being financed to perform the R\&D in the alliance. The date variable is expressed as a decimal (e.g., July 1, 1995 is coded as 1995.5). The stage of product measures are all dummy variables. The public equity raised variables are expressed in billions of 1995 dollars; the financial position variables in millions of 1995 dollars. The biotechnology index reflects public equity values and is normalized to 1.0 on January 1, 1978.

\begin{tabular}{|c|c|c|c|c|}
\hline $\begin{array}{l}\text { Variable } \\
\text { Date of Agreement }\end{array}$ & $\begin{array}{r}\text { Mean } \\
\text { July } 1991\end{array}$ & $\begin{array}{r}\text { Stan. Dev. } \\
3.1 \text { years }\end{array}$ & $\begin{array}{r}\text { Minimum } \\
\text { January } 1980\end{array}$ & $\begin{array}{r}\text { Maximum } \\
\text { December } 1995\end{array}$ \\
\hline \multicolumn{5}{|l|}{ Stage of Product at Time of Agreement: } \\
\hline Discovery/Lead Molecule & 0.63 & & 0 & 1 \\
\hline Pre-Clinical Development & 0.14 & & 0 & 1 \\
\hline Undergoing Regulatory Review & 0.22 & & 0 & 1 \\
\hline Approved for Sale & 0.01 & & 0 & 1 \\
\hline \multicolumn{5}{|l|}{ Condition of Biotech Equity Markets: } \\
\hline Public Equity Raised in Prior Quarter & 0.40 & 0.47 & 0 & 1.70 \\
\hline Public Equity Raised in Prior Four Quarters & 1.60 & 1.32 & 0 & 4.83 \\
\hline Biotech Index at End of Prior Quarter & 3.40 & 0.97 & 1.61 & 5.38 \\
\hline \multicolumn{5}{|l|}{ Patent Holdings of R\&D Firm: } \\
\hline Total Patent Awards & 5.32 & 14.44 & 0 & 114 \\
\hline Patent Awards Related to Agreement & 1.14 & 7.80 & 0 & 102 \\
\hline \multicolumn{5}{|l|}{ Financial Position of $R \& D$ Firm: } \\
\hline Revenues in Prior Year & 9.92 & 40.31 & 0 & 494.57 \\
\hline R\&D Expenditures in Prior Year & 11.17 & 21.32 & 0 & 229.11 \\
\hline Net Income in Prior Year & -11.13 & 30.75 & -284.06 & 47.69 \\
\hline Cash and Equivalents at End of Prior Year & 25.89 & 59.49 & 0 & 554.24 \\
\hline Total Assets at End of Prior Year & 48.45 & 119.64 & 0.49 & 1325.02 \\
\hline Shareholders' Equity at End of Prior Year & 33.44 & 86.62 & -17.08 & 1021.88 \\
\hline
\end{tabular}


Table 4-Percentage of agreements allocating control rights to the firm financing the R\&D activity. The sample consists of $\mathbf{2 0 0}$ technology strategic alliances initiated between biotechnology and pharmaceutical companies or between biotechnology firms in the 1980-1995 period. The table divides the tabulations into four chronological periods.

\begin{tabular}{|c|c|c|c|c|}
\hline Control Right & $1980-1987$ & 1988-1990 & 1991-1992 & $1993-1995$ \\
\hline \multicolumn{5}{|l|}{ Key Aspects of Alliance Management: } \\
\hline Right to Manage Clinical Trials & $64 \%$ & $62 \%$ & $46 \%$ & $62 \%$ \\
\hline Right to Undertake Process Development & 4 & 3 & 9 & 11 \\
\hline Right to Manufacture Final Product & 50 & 66 & 66 & 64 \\
\hline Right to Market Universally & 89 & 53 & 69 & 63 \\
\hline Right to Market Product Alone & 96 & 91 & 82 & 68 \\
\hline \multicolumn{5}{|l|}{ Determination of Alliance Scope: } \\
\hline Right to Expand Alliance & 7 & 9 & 7 & 15 \\
\hline Right to Extend Alliance & 32 & 25 & 21 & 18 \\
\hline Right to Terminate Alliance Without Cause & 46 & 50 & 33 & 18 \\
\hline Right to Terminate Particular Projects & 11 & 12 & 12 & 11 \\
\hline Right to Sub-License & 18 & 25 & 31 & 23 \\
\hline Right to License After Expiration/Termination & 39 & 41 & 54 & 41 \\
\hline Right to "Shelve" Projects & 96 & 94 & 99 & 86 \\
\hline \multicolumn{5}{|l|}{ Control of Intellectual Property: } \\
\hline Control of Patent Litigation & 29 & 25 & 22 & 25 \\
\hline Ownership of Patents & 18 & 6 & 7 & 10 \\
\hline Right to Know-How Transfer & 54 & 28 & 43 & 51 \\
\hline Ownership of Core Technology & 11 & 0 & 9 & 5 \\
\hline Right to Delay Publications & 14 & 22 & 33 & 51 \\
\hline Right to Suppress Publications & 32 & 9 & 16 & 19 \\
\hline \multicolumn{5}{|l|}{ Governance Structures: } \\
\hline Control of Top Project Management Body & 7 & 12 & 3 & 5 \\
\hline Seat on R\&D Firm's Board & 14 & 34 & 15 & 23 \\
\hline Equity in R\&D Firm & 32 & 56 & 45 & 62 \\
\hline Right to Participate in R\&D Firm's Financings & 18 & 34 & 21 & 15 \\
\hline Right to Register R\&D Firm's Stock & 18 & 25 & 36 & 33 \\
\hline Ability to Make Public Equity Purchases & 89 & 81 & 81 & 66 \\
\hline Mean Number of Restrictions & 8.9 & 8.7 & 8.6 & 8.5 \\
\hline Number of Observations & 28 & 32 & 67 & 73 \\
\hline
\end{tabular}


Table 5-Correlation between the control rights allocated to the funding party and (i) the financial market conditions around the time of the agreement and (ii) the characteristics of the firm being financed to perform the R\&D in the alliance. The sample consists of 200 technology strategic alliances initiated between biotechnology and pharmaceutical companies or between biotechnology firms in the 1980-1995 period. The table presents the correlation coefficients and p-values from the test of the null hypothesis that these coefficients are not significantly different from zero. The table uses the number of control rights included in each contract out of the five rights identified as key to alliance management, and out of the 24 rights appearing in between $5 \%$ and $95 \%$ of the contracts. The date variable is expressed as a decimal (e.g., July 1, 1995 is coded as 1995.5). The measure of the stage of the agreement is the ordinal rank of the process along a time-lime, with 1 being "discovery research" and 10 being "regulatory approval." The public equity raised and financial position variables are expressed in billions of 1995 dollars. The biotechnology index reflects public equity values and is normalized to 1.0 on January 1,1978 .

\begin{tabular}{|c|c|c|c|c|}
\hline & \multicolumn{2}{|c|}{ \# of Key Control Rights } & \multicolumn{2}{|c|}{ \# of Total Control Rights } \\
\hline & Corr. Coeff. & p-Value & Corr. Coeff. & p-Value \\
\hline Date of Agreement & -0.13 & 0.06 & -0.06 & 0.38 \\
\hline Stage of Product at Time of Agreement & -0.27 & 0.00 & -0.11 & 0.12 \\
\hline \multicolumn{5}{|l|}{ Condition of Biotech Equity Markets: } \\
\hline Public Equity Raised in Prior Quarter & -0.17 & 0.02 & -0.04 & 0.54 \\
\hline Public Equity Raised in Prior Year & -0.11 & 0.13 & -0.04 & 0.54 \\
\hline Biotech Index at End of Prior Quarter & -0.09 & 0.20 & -0.06 & 0.44 \\
\hline \multicolumn{5}{|l|}{ Patent Holdings of $R \& D$ Company: } \\
\hline Total Patent Awards & -0.26 & 0.00 & -0.09 & 0.21 \\
\hline Patent Awards Related to Agreement & -0.17 & 0.02 & -0.04 & 0.54 \\
\hline \multicolumn{5}{|l|}{ Financial Position of $R \& D$ Company: } \\
\hline Revenues in Prior Year & -0.21 & 0.00 & -0.12 & 0.09 \\
\hline R\&D Expenditures in Prior Year & -0.23 & 0.00 & -0.14 & 0.05 \\
\hline Net Income in Prior Year & 0.02 & 0.77 & 0.05 & 0.46 \\
\hline Cash and Equivalents at End of Prior Year & -0.21 & 0.00 & -0.17 & 0.02 \\
\hline Total Assets at End of Prior Year & -0.24 & 0.00 & -0.18 & 0.02 \\
\hline Shareholders' Equity at End of Prior Year & -0.24 & 0.00 & -0.17 & 0.02 \\
\hline
\end{tabular}




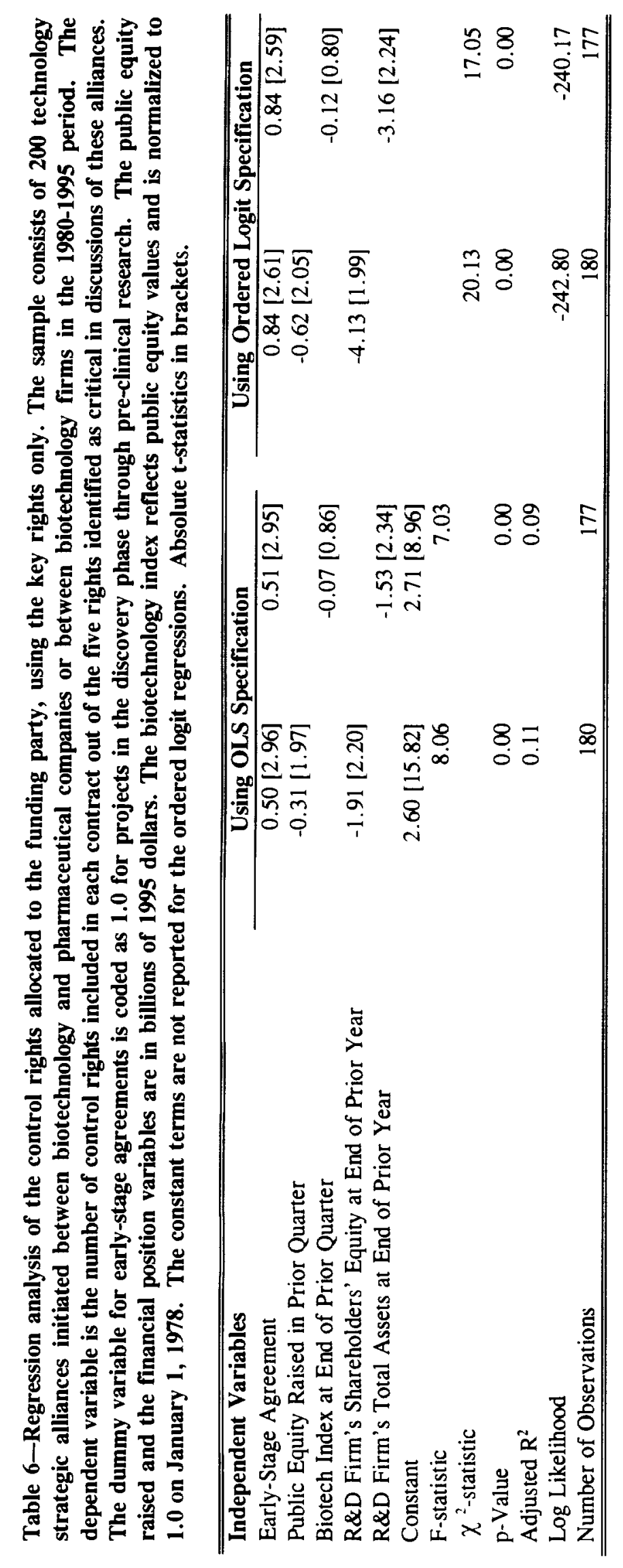




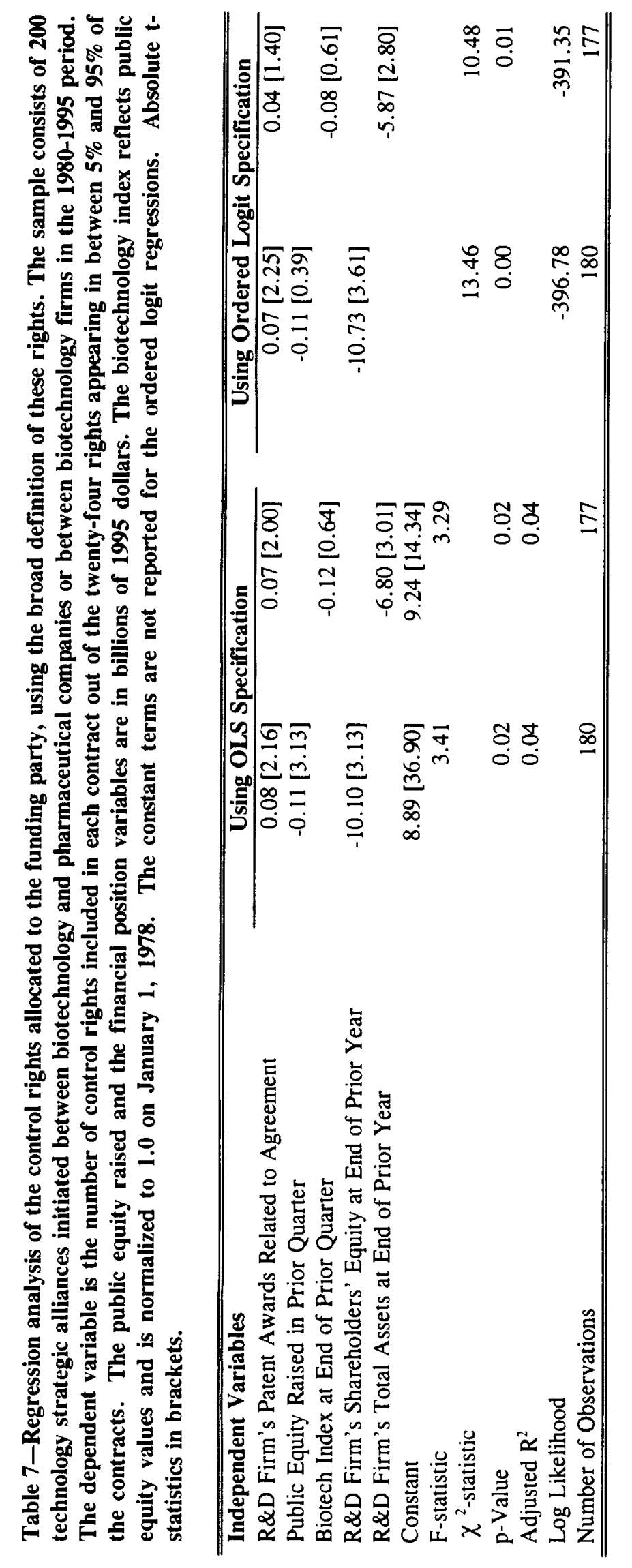

